\title{
Cloning, expression and characterization of thermostable YdaP from Bacillus licheniformis 9A
}

\author{
Joseph D. Wani Lako', Jada P. Yengkopiong ${ }^{1 凶}$, William H. L. Stafford ${ }^{2}$, Marla Tuffin ${ }^{3}$ and \\ Don A. Cowan ${ }^{4}$
}

1John Garang Memorial University of Science and Technology, College of Science and Technology, Bor, Jonglei State, Republic of South Sudan;

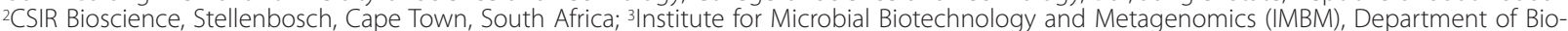
technology, University of the Western Cape, Bellville 7535, Cape Town, South Africa; ${ }^{4}$ Center of Genomics, University of Pretoria, Pretoria, South Africa

The Bacillus licheniformis ydaP gene encodes for a pyruvate oxidase that catalyses the oxidative decarboxylation of pyruvate to acetate and $\mathrm{CO}_{2}$. The YdaP form of this enzyme was purified about 48.6 -folds to homogeneity in three steps. The enzyme was recovered in a soluble form and demonstrated significant activity on pyruvate using 2, 6-dichlorophenolindophenol (DCPIP) as an artificial electron acceptor. HPLC analysis of the YdaP-enzyme catalysed conversion of pyruvate showed acetate as the sole product, confirming the putative identity of pyruvate oxidase. Analysis of the substrate specificity showed that the YdaP enzyme demonstrated preference for short chain oxo acids; however, it was activated by $1 \%$ Triton X-100. The YdaP substrate-binding pocket from the YdaP protein differed substantially from the equivalent site in all of the so far characterized pyruvate oxidases, suggesting that the $B$. licheniformis YdaP might accept different substrates. This could allow more accessibility of large substrates into the active site of this enzyme. The thermostability and $\mathrm{pH}$ activity of the YdaP enzyme were determined, with optimums at $50^{\circ} \mathrm{C}$ and $\mathrm{pH} 5.8$, respectively. The amino acid residues forming the catalytic cavity were identified as GIn460 to Ala480.

Key words: Bacillus licheniformis, pyruvate oxidase, YdaP, thiamine diphosphate enzyme

Received: 06 January, 2017; revised: 09 April, 2017; accepted: 11 April, 2017; available on-line: 15 March, 2018

e-mail: jadalojuka@yahoo.com.au

Abbreviations: POX, pyruvate oxidase, ThDP, thiamine diphosphate enzyme

\section{INTRODUCTION}

Thermophilic bacteria are a group of microorganisms that can grow and survive under broad environmental conditions, ranging from thermal pools to desert soils (Steele et al., 2008). This wide range of conditions indicates that the thermophilic bacteria produce enzymes that are stable and active under these extreme conditions. As a result, thermophilic bacteria are of interest to biotechnological and industrial applications because they work best at elevated temperatures.

Bacillus licheniformis is a thermophilic rod-shaped Gram-positive, facultative anaerobic bacterium, ubiquitous in nature and predominates soils (Claus \& Berkeley, 1986). It grows optimally at around $55^{\circ} \mathrm{C} . \mathrm{B}$. licheniformis has been widely used in biotechnology and industry to manufacture enzymes, including $\alpha$-amylase, cycloglucosyltransferase, $\beta$-mannanase, pectinolytic enzymes, penicillinase, pentosanase, proteases, antibiotics, biochemicals and other products (Eveleigh, 1981; Erickson, 1976). It is also used for microbial fermentations. As such, it is known as the 'industrial' bacterium. B. licheniformis genome has been sequenced (Rey et al., 2004), and it facilitates the production of other products with potential industrial uses.

The pyruvate oxidases (POX) are peripheral membrane associated flavoproteins belonging to the family of thiamine diphosphate dependent enzymes (Chang \& Cronan, 1995). They are studied due to their importance in biotechnological applications. This includes the production of acetate for the food and beverage industries, and as biocatalysts for the production of acetylphosphate and other chemical intermediates (Yoneda et al., 2001; Tomar et al., 2003; Yilmaztekin et al., 2008). POX enzymes are present in most bacteria, and those from Escherichia coli (Mather et al., 1982), Corynebacterium glutamicum (Schreiner \& Eikmanns, 2005), Staphylococcus aureus (Patton et al., 2005), Aerococcus viridans (Juan et al., 2007) and Lactobacillus plantarum (Sedewitz et al., 1984; Goffin et al., 2006; Lorquet et al., 2004) have been well characterized. These enzymes are divided into two subfamilies (Bertaggnolli \& Hager, 1991). Subfamily I (EC 1.2.3.3), catalyzes the oxidative decarboxylation of pyruvate in the presence of oxygen and inorganic phosphate, generating hydrogen peroxide and acetylphosphate. Subfamily II (EC 1.2.5.1) catalyzes the oxidative decarboxylation of pyruvate, generating acetate and carbon dioxide in the presence of ferricytochrome $b 1$ as an electron acceptor (Blake et al., 1982). These previously characterized pyruvate oxidases were shown to have activity at moderate temperatures (Sedewitz et al., 1984). Pyruvate oxidases are strongly activated by low concentrations of phospholipids and detergents (Chang \& Cronan, 1986; Hamilton, 1986; Schreiner \& Eikmanns, 2005). The phospholipid activation occurs by an association with the protein and is accompanied by conformational changes and alteration of various properties of the enzyme (Wang et al., 1991).

The objective of this study was to biochemically characterize the $B$. licheniformis $Y d a P$, originally annotated in the genome database to be a pyruvate decarboxylase, and would have been the first representative from a thermotolerant organism. Here, we report on the thermostable activity of $\mathrm{YdaP}$, as a pyruvate oxidase. We show that this enzyme has significant activity at $50^{\circ} \mathrm{C}$ to produce acetate from pyruvate. 


\section{MATERIALS AND METHODS}

Materials. All biochemical reagents used in this study were purchased from Sigma Aldrich or Fluka, Germany.

Isolation of B. licheniformis 9A. B. licheniformis 9A was isolated from soil collected from the Karoo region (Northern Cape Province, South Africa). Unless otherwise stated, B. licheniformis 9A was grown aerobically at $50^{\circ} \mathrm{C}$ for 18 hours in $50 \mathrm{ml}$ Tryptone Soya Broth (TSB) supplemented with glucose $(0.25 \%)$ as a carbon source, with shaking at $150 \mathrm{rpm}$. The isolate was identified by analyzing the 16S rRNA gene sequence generated with species specific primers from genomic DNA isolated as described previously (Miller et al., 1999). The 16S rRNA PCR product was cloned into the pTZ57R/T vector (Fermentas Life Science) and transformed into E. coli Genehogs (Novagen) according to the manufacturer's instructions.

Cloning and Overexpression of the B. licheniformis 9A YdaP. Primers specific to the annotated ydaP gene (Accession number CBE70488) were designed: YdaP-F (5'-ATGGATGGCAAACAAAACCGCAG-3') and YdaP-R (5'-TAGGCGATCTCCCT'TGGCATCATAC-3') incorporating the $\mathrm{NcoI}$ and $\mathrm{BamHI}$ restriction sites (underlined). The PCR thermocycling conditions were set as $95^{\circ} \mathrm{C}$ for $5 \mathrm{~min}$, followed by 30 cycles of $95^{\circ} \mathrm{C}$ for $1 \mathrm{~min}, 57^{\circ} \mathrm{C}$ for $4 \mathrm{~min}$ and $72^{\circ} \mathrm{C}$ for $2 \mathrm{~min}$, and the extension step of $72^{\circ} \mathrm{C}$ for $1 \mathrm{~min}$. The PCR product was cloned into pET-28a (Novagen), and transformed into E. coli Genehogs. The 1719 bp ydaP gene was amplified from genomic DNA cloned into the vector. The inserts from a selection of transformants were sequenced to identify a clone without PCR errors, which was subsequently transformed into E. coli Rosetta2 pLysS (Novagen) for overexpression of $\mathrm{YdaP}$. Overexpression was conducted in an auto-induction medium (Grabski et al., 2005), containing Kanamycin (25 mg/ml) and chloramphenicol (25 mg/ml), and incubated aerobically for $16-24$ hours at $37^{\circ} \mathrm{C}$. Cells were harvested by centrifugation at $10000 \times g$ and lysed with the Bugbuster extraction reagent (Novagen), supplemented with a Benzonnase nuclease (Novagen). The cellular debris was removed by centrifugation at $10000 \times g$ for $15 \mathrm{~min}$ at $4^{\circ} \mathrm{C}$, and the crude extract was used for $\mathrm{YdaP}$ purification.

Purification of recombinant YdaP protein. Proteins in the crude extract were precipitated with $30 \%$ saturated ammonium sulphate, and incubated on ice for one hour. Following $0.22 \mu \mathrm{M}$ filtration, the supernatant was used for hydrophobic interaction chromatography on a HiLoad ${ }^{\mathrm{TM}}$ Phenyl Sepharose XK16 column. The unbound proteins were eluted in buffer A $(50 \mathrm{mM}$ potassium phosphate, $1 \mathrm{M}$ ammonium sulfate $\mathrm{pH}$ 5.8). The bound protein was eluted with a linear gradient of decreasing salt concentration (1 M ammonium sulfate in $25 \mathrm{mM}$ potassium phosphate buffer $(\mathrm{pH} 5.8)$ at a flow rate of $2 \mathrm{ml} \mathrm{min}{ }^{-1}$. Fractions showing activity where loaded onto a HiLoad ${ }^{\mathrm{TM}}$ 26/10 Q-Sepharose XK26 ion exchange column that was pre-equilibrated with $25 \mathrm{mM}$ potassium phosphate buffer $\mathrm{pH} 5.8$ (Buffer B). The unbound proteins were eluted in 5 column volumes of Buffer B. The bound protein was eluted using a linear gradient of increasing salt concentration from 0 to $1 \mathrm{M}$ sodium chloride in $25 \mathrm{mM}$ potassium phosphate buffer

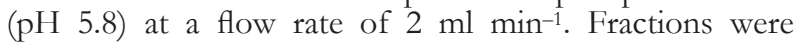
collected, pooled, concentrated and tested for activity, and stored at $-20^{\circ} \mathrm{C}$.

Zymogram assay. YdaP activity was detected by staining the non-denaturing PAGE gel electrophoresis using a staining solution consisting of pyruvate as a sub- strate with TPP and $\mathrm{MgCl}_{2}$ dissolved in $0.1 \mathrm{M}$ potassium phosphate buffer ( $\mathrm{pH} 5.8$ ), and 2,6-dichlorophenolindophenol (DCPIP) as an electron acceptor. The molecular weight of the active $\mathrm{YdaP}$ protein was estimated by using 10\% Native-PAGE electrophoregram.

Pyruvate oxidase enzyme assays. The purified $\mathrm{YdaP}$ enzyme was assayed for pyruvate oxidase activity (EC 1.2.5.1) based on the reduction of 2,6-dichlorophenolindophenol (DCPIP) [20]. The reaction mixtures contained $250 \mathrm{mM}$ potassium phosphate buffer ( $\mathrm{pH} 5.8$ ), $1 \mathrm{mM}$ TPP, $2 \mathrm{M}$ sodium pyruvic acid, $100 \mathrm{mM} \mathrm{MgCl}_{2}$ and $1 \%$ Triton $\mathrm{X}-100(\mathrm{v} / \mathrm{v})$. The control contained purified enzyme and pyruvate was substituted with $\mathrm{dH}_{2} \mathrm{O}$. After the reaction mixtures were prepared, $100 \mu \mathrm{l}$ of the purified enzyme was added and incubated at $25^{\circ} \mathrm{C}$ for $20 \mathrm{~min}$, followed by addition of $100 \mu \mathrm{l}$ of $300 \mu \mathrm{M}$ 2,6-dichlorophenolindophenol (DCPIP). Changes in absorbance were monitored spectrophotometrically at 450 $\mathrm{nm}$. The enzymatic activity was calculated using $\varepsilon=0.218$ $\mathrm{mM}^{-1} \mathrm{~cm}^{-1}$ (Cunningham \& Hager, 1971; Blake \& Hager, 1978). One unit (1U) of the YdaP activity was defined as the amount of YdaP catalyzing the production of $1 \mu \mathrm{M}$ of acetate per min from pyruvate at $25^{\circ} \mathrm{C}$. The activity of the YdaP enzyme was determined in $100 \mathrm{mM}$ sodium phosphate/citrate buffers with $\mathrm{pH}$ values ranging from 4.6 to 6.0 and $100 \mathrm{mM}$ potassium phosphate buffers in the $\mathrm{pH}$ range of 5.8 to 7.4 , at $22^{\circ} \mathrm{C}$. The rates of reaction were monitored and the absorbance was measured at $\mathrm{OD}_{450 \mathrm{~nm}}$ in $1 \mathrm{~cm}$ path length cuvettes. Thermostability assay was conducted by incubating $\mathrm{YdaP}$ preparations at a range of 30 to $80^{\circ} \mathrm{C}$ in $50 \mathrm{mM}$ potassium phosphate buffer ( $\mathrm{pH} 5.8$ ) and 1\% Triton X-100 was added for enzyme activation for $20 \mathrm{~min}$, and the percentage residual activity was recorded. Various $\alpha$-keto acid substrates were tested, including sodium pyruvate, $\alpha$-ketobutyric acid, 3-methyl-2-oxopentanoic acid, indole-3-pyruvic acid, 4-hydroxyphenylpyruvic acid and phenylglyoxylic acid. The kinetic constants were determined using the direct linear plot of Eisenthal and Cornish-Bowden (1974), assayed at $50^{\circ} \mathrm{C}$ in $100 \mathrm{mM}$ potassium phosphate buffer at the $\mathrm{pH}$ of 5.8 .

HPLC Analysis of acetate production. The assay mixture $(1 \mathrm{ml})$ contained $40 \mathrm{mM}$ potassium phosphate buffer ( $\mathrm{pH}$ 5.8), $10 \mathrm{mM} \mathrm{MgCl}, 10 \mu \mathrm{M}$ TPP, $10 \mathrm{mM}$ sodium pyruvate and purified $\mathrm{YdaP}$ enzyme, and was incubated at $25^{\circ} \mathrm{C}$ for $20 \mathrm{~min}$. The reaction mixture was centrifuged for $5 \mathrm{~min}$ at $16200 \times \mathrm{g}$ before HPLC analysis. Reaction products were separated on a Rezex RHM monosaccharide $\mathrm{H}^{+}(8 \%)$ column (Phenomenex, USA) using $5 \mathrm{mM}$ sulfuric acid as the mobile phase (Okuyama et al., 1989). The flow rate was set at $0.5 \mathrm{ml} / \mathrm{min}$; the column oven temperature was $40^{\circ} \mathrm{C}$ and pressure was set at 32 bars with an injection volume of $20 \mu \mathrm{l}$. The compounds were detected using RI and UV detectors, set to $215 \mathrm{~nm}$, and compared to standards.

Nucleotide sequence analysis. DNA sequences were analysed using DNAMAN (Lynnon BioSoft) and Bio-Edit version 5.0.9 software (Hall, 1999). Comparison searches were performed using the gapped-BLAST program at the National Centre for Biotechnology Information (Altschul et al., 1997). Multiple sequence alignments were performed using ClustalW. The YdaP molecular weight was determined using DNAMAN and $\mathrm{pI}$ was predicted using the EXPASY website (www.expasy. $\operatorname{org} /)$. The B. licheniformis $9 \mathrm{~A} y d a \mathrm{P}$ gene sequence was deposited in the GenBank database under accession number CBE70488.

Homology modeling. The threading programs FUGUE (Shi et al., 2001) and MODELLER 9v4 (Sali, 
Table 1. Blast (nucleotides) search results for the Bacillus 9A isolate 16S rRNA gene.

\begin{tabular}{lllc}
\hline Strains & Accession number & Identity (\%) & $E_{\text {value }}$ \\
\hline B. licheniformis ATCC 14580 & CP000002 & $1537 / 1569(97 \%)$ & 0.0 \\
\hline B. licheniformis DSM 13 & AE017333 & $1537 / 1569(97 \%)$ & 0.0 \\
\hline B. licheniformis strain N8 & DQ350834 & $1518 / 1551(97 \%)$ & 0.0 \\
\hline B. licheniformis & X684116 & $1520 / 1554(97 \%)$ & 0.0 \\
\hline B. licheniformis strain MML2501 & EU344793 & $1517 / 1551(97 \%)$ & 0.0 \\
\hline
\end{tabular}

1995) were used to generate structural YdaP models, using the L. plantarum POX (PDB 2EZ9) as a template. Stereochemical analysis of the $\mathrm{YdaP}$ structure was carried out using RAMPAGE (Lovell et al., 2001).

\section{RESULTS}

The 16S rRNA sequence analysis showed $97 \%$ identity to $B$. licheniformis, designated isolate $9 \mathrm{~A}$ in this study (Table 1). Sequence analysis revealed $1537 / 1569$ bp differences compared to the $y d a P$ gene sequence for $B$. licheniformis ATCC 14580 and contained a low $\mathrm{mol} \% \mathrm{G}+\mathrm{C}$ content $(49 \%)$.

The gene sequence encoded a putative protein of 573 amino acids with an estimated molecular weight of approximately $63 \mathrm{kDa}$, with a $\mathrm{pI}$ value of 5.83 . The $\mathrm{YdaP}$ protein had shown identity to thiamine-dependent family proteins, contain-

IdaP Bacillus licheniformis DS Poos Staphylococous aureus subs PDI Corynebacterium glutamicum PDII (Poor) E. coli

Poos Iactobacillus plantarum Pook Aerococcus viridans

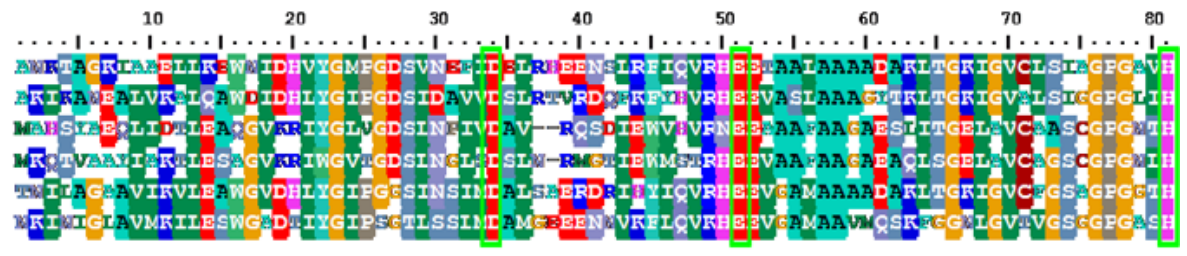

IdaP Bacillus licheniformis DS Poor staphylococous aureus subs PDI Corynebacterium glutamicum FDH (Poos) E. coli

Poor Inctobacillus plantarum Pook Aerococous viridans

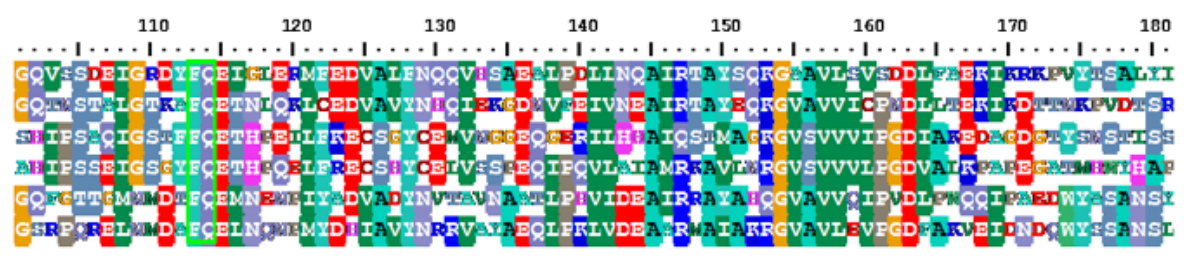

rdaP Bacillus licheniformis DS Poor Staphylococous aureus subs PDI Corynebacterium glutamicum PDII (Poor) E. coli

Poor Iactobacillus plantarum Poor Aerococcus viridans

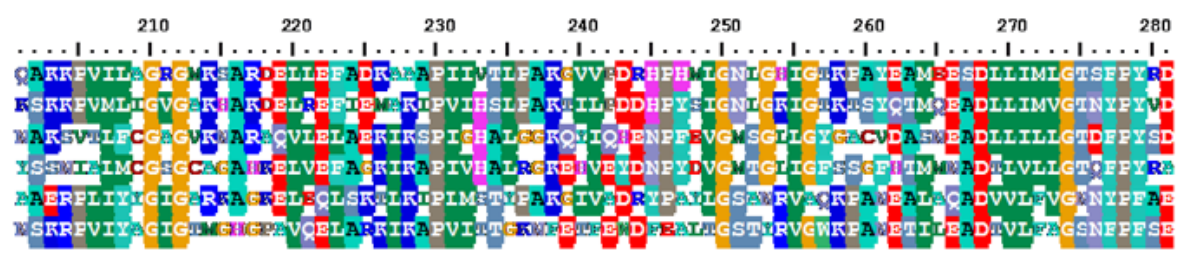

IdaP Bacillus licheniformis DS Pook Staphylococous aureus subs FDH Corynebacterium glutamicum PDH (Pook) E. coli

Pook Inctobacillus plantarum Poos Aerococous viridans

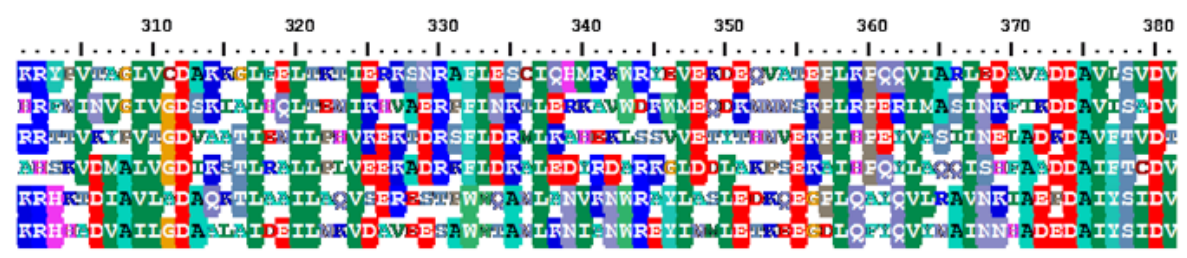

IdaP Bacillus licheniformis DS Poos Staphylococous aureus subs PDI Corynebacterium glutamicum PDII (Poor) E. coli

Poos Iactobacillus plantarum Pook Aerococous viridans

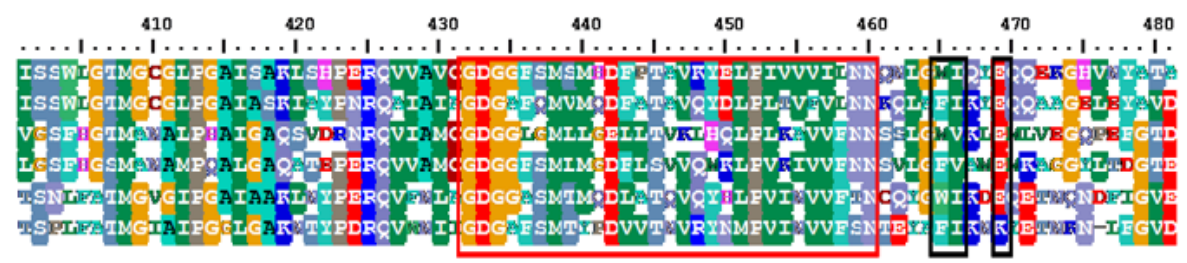

IdaP Bacillus licheniformis DS Poos Staphylococous aureus subs EDH Corynebacterium glutamicum PDH (Poos) E. coli

Pook Inctobacillus plantarm Poor Aerococous viridans

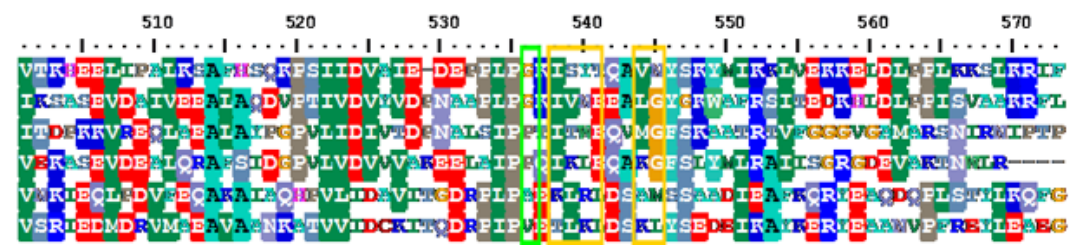

Figure 1. Multiple sequence alignments of B. licheniformis YdaP with pyruvate oxidase from S. aureus, pyruvate oxidase from C. glutamicum, PDH from E. coli, L. plantarum and A. viridans.

Catalytic residues are indicated with the black boxes, the ThDP binding site is indicated with the red box and the substrate binding sites are indicated with the yellow boxes. Residues indicated with the green boxes are highly conserved, and thought to be involved in catalysis. 


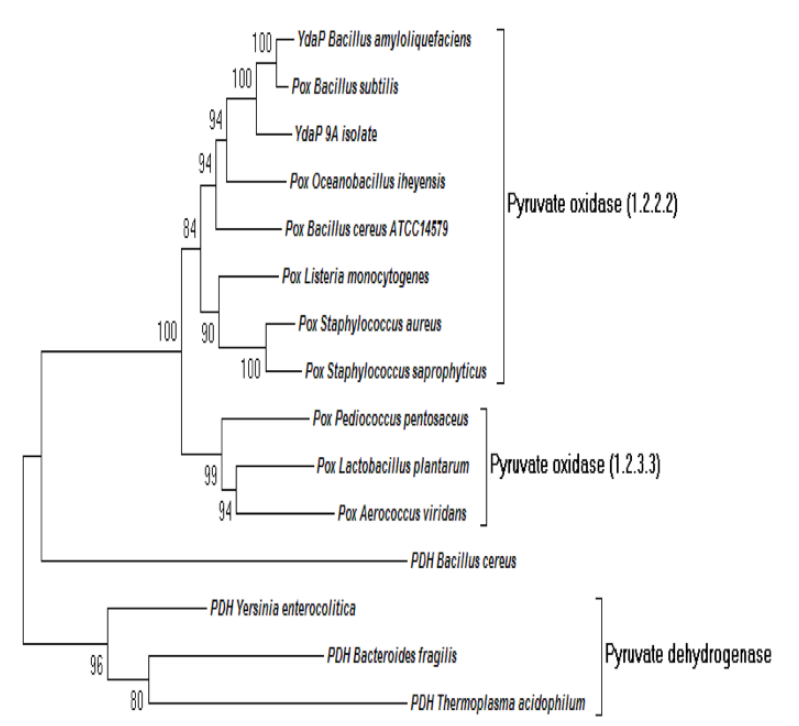

0.2

Figure 2. Phylogenetic alignment of $B$. licheniformis $9 A$ YdaP in relation to uncharacterized YdaP sequences identified in other Bacillus sequences from the GenBank database, and representatives of the EC 1.2.3.3 and EC 1.2.2.2 type POX enzymes.

ing the signature motif at amino acid positions G431N459 (Fig. 1). A high level of identity was also seen with the uncharacterized $y d a P$ genes from many other Bacillus organisms (B. subtilis NP 388315, 75\%; B. pumilus YP $0014855662,73 \%$; B. amyloliquefaciens YP 00420086, 72\%; and $B$. cereus ZP $03232334,54 \%$ ). Although only $75 \%$ sequence identity was observed with the EC 1.2.3.3 pyruvate oxidases, all of the Bacillus ydaP sequences clustered with this group of enzymes (Fig. 2).

The expression of $B$. licheniformis $\mathrm{YdaP}$ using the $\mathrm{pET}$ system enables rigorous control of gene expression. A high level of YdaP expression was achieved under optimized conditions (San et al., 1994). Crude cell extracts were analysed by SDS-PAGE (Fig. 3). A protein band was evident at approximately $63 \mathrm{kDa}$, corresponding to the predicted molecular weight of B. licheniformis YdaP.

The purified YdaP enzyme showed a distinct band on SDS-PAGE. The subunit molecular weight was calculated to be approximately $63 \mathrm{kDa}$ (Fig. 3). The YdaP protein showed identity to thiamine-dependent family proteins containing the signature motif at amino acid po-

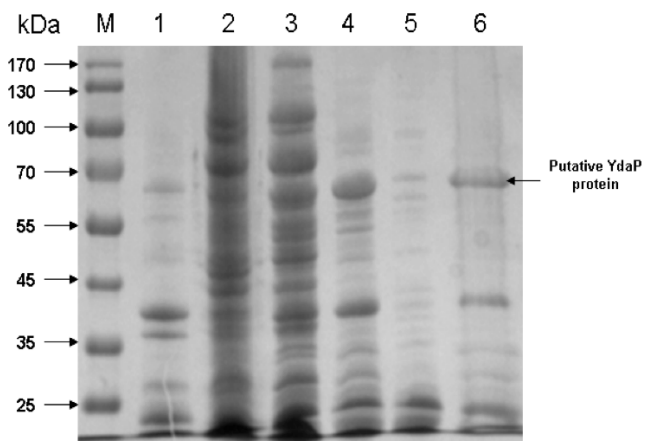

Figure 3. $12 \%$ SDS-PAGE gel electrophoresis showing the expression of YdaP with pET-28a (+) expression vector.

Lane M: Molecular weight marker; Lane 1: pET28a in E. coli; Lane 2: soluble fraction; Lane 3: soluble fraction; Lane 4: soluble fraction; Lane 5: soluble fraction treated at $65^{\circ} \mathrm{C}$; Lane 6: Ammonium sulfate treatment.

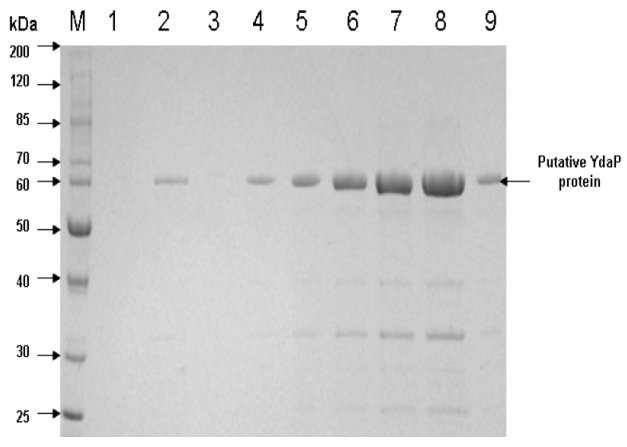

Figure 4. (A) Q-Sepharose ion exchange chromatography of B. licheniformis YdaP (B) 10\% SDS-PAGE electrophoregram; Lane M: Molecular weight marker; Lane 1: Flow-through fraction of YdaP protein; Lane 2: First fraction of YdaP soluble protein; Lane 4-9: Second fraction of the soluble of putative YdaP protein.

sitions G431- N459 (Hawkins et al., 1989) (Fig. 1). This finding is in complete agreement with previous studies of other POX proteins (Patton et al., 2005, Schreiner \& Eikmanns, 2005). Crude extracts of B. licheniformis $\mathrm{YdaP}$ (with a specific activity of $0.1 \mathrm{U} / \mathrm{mg}^{-1}$ ) were subjected to ammonium sulfate precipitation. This method does not result in detrimental effects on the enzyme activity and was employed to facilitate the binding of the crude enzyme to the hydrophobic interaction chromatography matrix. A $30 \%(\mathrm{w} / \mathrm{v})$ ammonium sulfate concentration was used and resulted in an increase in $\mathrm{YdaP}$ specific activity to $2.62 \mathrm{U} / \mathrm{mg}^{-1}$ (Table 2). Following hydrophobic interaction chromatography, ion exchange chromatography was used to further purify the active B. licheniformis YdaP protein. This strategy achieved the highest purification level (Zhang \& Hager, 1987) of the YdaP enzyme, as determined by SDS-PAGE (Fig. 3). Fractions exhibiting the $\mathrm{YdaP}$ protein activity were collected, pooled and concentrated for further characterization.

The molecular weight of the active $\mathrm{YdaP}$ protein was estimated to be approximately $250 \mathrm{kDa}$, which represent the active form of the YdaP enzyme (Fig. 5). This observation implies that the $\mathrm{YdaP}$ protein is a homotratermer. YdaP activity was detected by staining the non-denaturing PAGE gel electrophoresis using a staining solution consisting of pyruvate as a substrate, with TPP and $\mathrm{MgCl}_{2}$ dissolved in $0.1 \mathrm{M}$ potassium phosphate buffer (pH 5.8), and 2,6-dichlorophenolindophenol (DCPIP) as an electron acceptor. The reaction resulted in the formation of a white precipitate in the gel (Fig. 4), and this

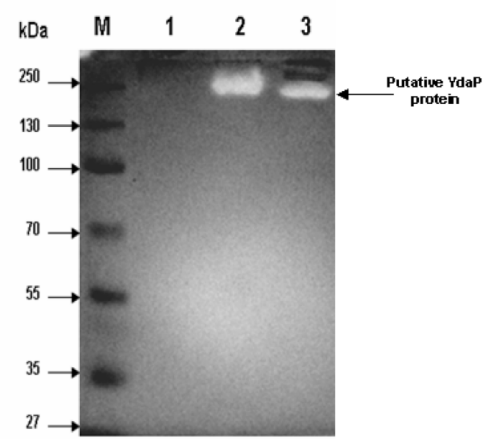

Figure 5. 10\% Native-PAGE electrophoregram showing the YdaP activity;

Lane M: Molecular marker; Lane 1: E. coli/pET28a vector; Lane 2: Crude cell extracts of YdaP enzyme; Lane 3: Semi-purified YdaP enzyme (HIC fraction). 
Table 2. Summary of the YdaP purification steps.

\begin{tabular}{|c|c|c|c|c|c|c|}
\hline Sample & $\begin{array}{l}\text { Volume } \\
(\mathrm{ml})\end{array}$ & Total Protein (mg) & $\begin{array}{l}\text { Total Activity } \\
\text { (U) }\end{array}$ & Specific Activity (U/mg) & $\begin{array}{l}\text { Yield } \\
(\%)\end{array}$ & $\begin{array}{l}\text { Purification } \\
\text { (fold) }\end{array}$ \\
\hline Crude extract & 15 & 795 & 303 & 0.1 & 100 & 1 \\
\hline$\left(\mathrm{NH}_{4}\right)_{2} \mathrm{SO}_{4}$ precipitation & 15 & 138 & 67.1 & 2.62 & 17 & 26.2 \\
\hline Phenyl-Sepharose & 15 & 116 & 54 & 4.86 & 15 & 48.6 \\
\hline
\end{tabular}

Table 3. Effect of temperature on YdaP stability

\begin{tabular}{lc}
\hline Temperature $\left({ }^{\circ} \mathrm{C}\right)$ & Relative activity $(\%) \pm$ S.D. \\
\hline 30 & $86 \pm 4.0$ \\
\hline 40 & $87 \pm 4.3$ \\
\hline 50 & $100 \pm 4.4$ \\
\hline 60 & $82 \pm 4.9$ \\
\hline 70 & $13 \pm 1.1$ \\
\hline 80 & $11 \pm 1.1$ \\
\hline
\end{tabular}

observation confirmed that the stained band corresponded to the B. licheniformis YdaP.

The $\mathrm{pH}$ activity-profile of $B$. licheniformis $\mathrm{YdaP}$ was performed over the $\mathrm{pH}$ range of 4.6 to 7.4 (Fig. 4.10). $\mathrm{YdaP}$ showed maximum activity at $\mathrm{pH}$ 5.8. This $\mathrm{pH}$ optimum is slightly lower than values reported for the E. coli, L. plantarum (Lorquet et al., 2004) and A. viridans POX (Juan et al., 2007), all of which show optimal values at $\mathrm{pH}$ 6.0. The B. licheniformis $\mathrm{YdaP}$ retained approximately $50 \%$ activity at $\mathrm{pH}$ values of 5.4 and 6.5 , and had detectable activity in the range from $\mathrm{pH} 4.6$ to 7.4.

The enzyme was found to perform optimally at $50^{\circ} \mathrm{C}$ (Table 3) and pH 5.8 (Fig. 6). The activity was stable at $50^{\circ} \mathrm{C}$, but was rapidly inactivated at higher temperatures, retaining only $11 \%$ of initial activity at $80^{\circ} \mathrm{C}$ (Fig. 6).

$\mathrm{YdaP}$ activity was tested on a range of different substrates (Table 4). The highest activity was achieved with pyruvate (C3), and activity decreased as the substrate chain length increased (Table 4). Low activity was detected with aromatic and larger branched chain substrates.

Kinetic constants were estimated as averages of values calculated from a direct linear plot. The purified recombinant YdaP displayed similar substrate affinities and rates of reaction to both, the crude extract and partially purified enzyme. The recombinant enzyme had a $K_{\mathrm{M}}$ of $4.4 \mathrm{mM}$ for pyruvate and a $V_{\max }$ of $4.86 \mathrm{U} / \mathrm{mg}$ protein, and $K_{\text {cat }}$ of $25.3 \mathrm{~s}^{-1}$ (Table 5) when assayed at a temperature of $50^{\circ} \mathrm{C}$ and a $\mathrm{pH}$ of 5.8 . The recombinant enzyme

Table 4. Comparison of the substrate specificities of the YdaP enzyme of B. licheniformis 9A strain

\begin{tabular}{llll}
\hline Substrate & Carbon number & Structure & Relative activity (\%) \\
\hline Pyruvic acid & C3 & il & $100 \pm 0.0$
\end{tabular}




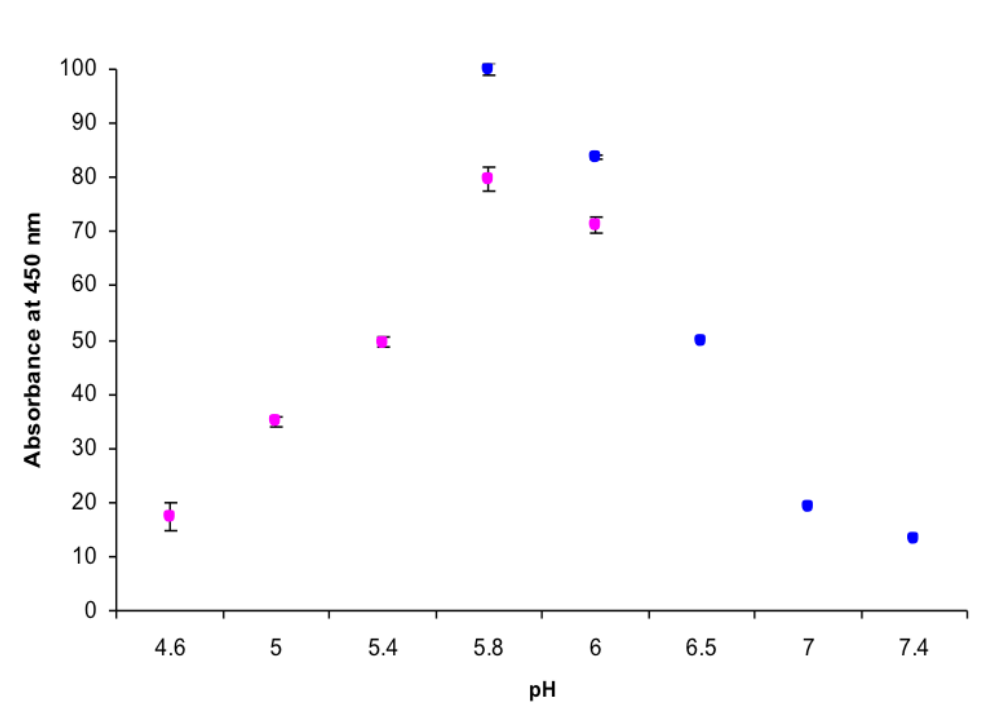

Figure 6. $\mathrm{pH}$ profile of the recombinant $\mathrm{YdaP}$ based on relative activity at $50^{\circ} \mathrm{C}$ and at different $\mathrm{pH}$ values. YdaP showed maximum activity at $\mathrm{pH} 5.8$.

Table 5. The kinetic data of the partially purified YdaP on pyruvate substrate

\begin{tabular}{lllll}
\hline Sample & $K_{\mathrm{m}}(\mathrm{mM})$ & $V_{\text {max }}(\mathrm{U} / \mathrm{mg})$ & $k_{\mathrm{cat}}\left(\mathrm{s}^{-1}\right)$ & $k_{\mathrm{cat}} / K_{\mathrm{m}}\left(\mathrm{s}^{-1} \mathrm{mM}^{-1}\right)$ \\
\hline Phenyl-Sepharos (HIC) & 4.4 & 4.86 & 25.3 & 11.5 \\
\hline
\end{tabular}

displayed a higher affinity for pyruvate than C. glutamicum POX (30 mM) (Schreiner \& Eikmanns, 2005).

For the HPLC analysis of $B$. licheniformis $\mathrm{YdaP}$ enzyme, pyruvate and acetate were selected as standards for quantification using the Rexez RHM H $\mathrm{H}^{+}$column. Various HPLC conditions were tested to achieve the best resolution of acetate as a standard. The retention time of acetate was $15.44 \mathrm{~min}$. A single product peak was detected using pyruvate as substrate with $B$. licheniformis YdaP preparations, corresponded exactly to the acetate peak generated with the standard. Acetate was detected in all $\mathrm{YdaP}$ reactions at pyruvate substrate concentrations ranging from $10 \mathrm{mM}$ to $200 \mathrm{mM}$. However, in all reactions, the estimated acetate yield was approxi-

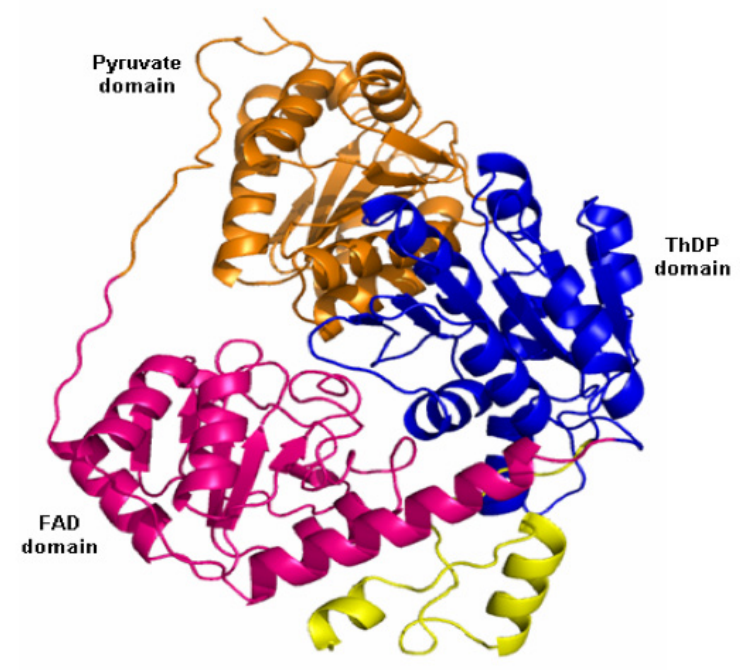

Figure 7. Cartoon representation of the Bacillus licheniformis $9 A$ YdaP monomer, showing the three-domain structure of the YdaP subunit. mately $1 \mathrm{mM}$; that is, the product yield did not correlate with the substrate concentration.

The YdaP model was generated using the L. plantarum POX (PDB 2EZ9) as a template, which shares $35 \%$ sequence identity to $\mathrm{YdaP}$. The model of the YdaP monomer (Fig. 7) is compatible with the $\alpha / \beta$ topology observed in all of the crystallized TPP-dependant decarboxylases (Wille et al., 2006, Juan et al., 2007), comprising the N-terminal Pyruvate domain, FAD domain and the C-terminal ThDP domain.

\section{DISCUSSION}

Phylogenetic analysis using closely related 16S rRNA gene sequences from other bacterial species had shown that phylogenetically, the $9 \mathrm{~A}$ isolate was very closely related to other Bacillus species. The species of licheniformis, amyloliquefaciens (Priest et al., 1987), subtilis (Priest et al., 1988) and cereus (Radnedge et al., 2003) were closest to the $9 \mathrm{~A}$ isolate (Fig. 2). GenBank analysis and alignment studies revealed that the $B$. licheniformis $9 \mathrm{~A}$ strain $y d a \mathrm{P}$ gene was encoding a pyruvate oxidase (POX; EC 1.2.5.1). The significantly high sequence identity between homologous genes of these species suggested that they were closely related; they encoded an uncharacterized pyruvate oxidase. Sequence alignment analysis revealed that this group of enzymes belongs to the family of ThDP dependent enzymes responsible for the decarboxylation of pyruvate. B. licheniformis $\mathrm{YdaP}$ shared many biochemical properties with other pyruvate oxidases, including C. glutamicum POX (Patton et al., 2005; Schreiner \& Eikmanns, 2005), other than its thermostability. The B. licheniformis YdaP enzyme represents a new subfamily of pyruvate oxidases. This result was based on the phylogenetic tree as the pyruvate oxidases group together under the same cluster, however, the YdaP enzyme is forming a new clade with the Bacillus genera (Fig. 2).

The homology analysis of amino acids deduced from the $y d a P$ gene sequence demonstrates much less identity with the acetyl-phosphate and $\mathrm{H}_{2} \mathrm{O}_{2}$ forming pyruvate oxidases (POX; EC 1.2.3.3) of L. plantarum (35\%). In contrast, the fact that the $B$. licheniformis $\mathrm{YdaP}$ enzyme reaction is phosphate independent and that the product of the B. licheniformis $\mathrm{YdaP}$ enzyme reaction is acetate instead of acetyl-phosphate argue against a close relationship between the $B$. licheniformis $\mathrm{YdaP}$ enzyme and the lactobacterial and E. coli pyruvate oxidases.

Comparative analysis of the complete amino acid sequence of $B$. licheniformis $\mathrm{YdaP}$ using PCR specific primers based on the $y d a P$ gene sequence, aligned with $S$. aureus, C. glutamicum, E. coli, L. plantarum and A. viridans (EC 1.2.3.3), provided some information based on their ThDP domains and is high enough to directly infer into their evolutionary relationships. Overall phylogeny analysis of these pyruvate oxidase (EC 1.2.5.1) sequences had shown them to group together, forming a single cluster. Based on their sequence divergence, the apparently observed phylogenetic cluster of this group was subsequently divided into two distinct clades and was supported by a bootstrap value of $84 \%$. 
The B. licheniformis YdaP enzyme was purified from cell extracts and most of the activity was found in the soluble cytoplasmic fraction. The enzyme was shown to be activated by the Triton X-100 detergent. A variety of the membrane associated enzymes have been shown to require detergents for their catalytic activity, with the pyruvate oxidase from E. coli among them (Blake, 1982). The $\mathrm{YdaP}$ has unique characteristics differentiating it from previously characterized EC 1.2.5.1 pyruvate oxidases (Neale et al., 1987), in that it displays thermostability and catalyzes reactions with a broad range of substrates including linear, branched and aromatic oxo acids. As for the other pyruvate oxidases (Schreiner \& Eikmanns, 2005), YdaP displays Michaelis-Menten kinetics with pyruvate as substrate, however, YdaP showed higher affinity for pyruvate $\left(K_{\mathrm{m}}=4.4 \mathrm{mM}\right)$ when compared to that of C. glutamicum $\left(K_{\mathrm{m}}=30 \mathrm{mM}\right)$ (Schreiner \& Eikmanns, 2005). This enzyme is a homotetrameric flavoproteins consisting of $63 \mathrm{kDa}$ subunits with tightly bound FAD, and it requires TPP and a divalent metal cation such as $\mathrm{Mg}^{2+}, \mathrm{Mn}^{2+}$ and $\mathrm{Co}^{2+}$ for enzymatic activity.

Biochemical characterization of the B. licheniformis $9 \mathrm{~A} \mathrm{YdaP} \mathrm{indicated} \mathrm{that} \mathrm{it} \mathrm{was} \mathrm{a} \mathrm{pyruvate} \mathrm{oxidase} \mathrm{(EC}$ 1.2.5.1), catalyzing the oxidative decarboxylation of pyruvate to generate acetate and carbon dioxide. Due to the high sequence identity to the annotated B. licheniformis genome $\mathrm{YdaP}(97 \%)$, we propose that the Bacillus ydaP genes encode a pyruvate oxidase, and not in fact a pyruvate decarboxylase. Refinement of the annotation has subsequently re-classified the $y d a P$ gene as a pyruvate oxidase as we have shown. This illustrates the danger in assigning function based on the sequence data alone, but also how the bioinformatics tools have improved in recent years to generate more reliable annotations.

This study demonstrated that the B. licheniformis $\mathrm{YdaP}$ is more stable compared to pyruvate oxidases from other microorganisms (Neumann et al., 2008; Patton et al., 2005). The enzyme was stable at higher temperatures than other pyruvate oxidases, such as the E. coli POX (temperature-stability of $25^{\circ} \mathrm{C}$ and $\mathrm{pH}$ 6.0) (Mather \& Gennis, 1985).

Investigations of the substrate specificity of the $B$. licheniformis $\mathrm{YdaP}$ enzyme showed a higher specific activity for pyruvate than for $\alpha$-ketobutyric acid $(23 \%)$, 3-methy2-oxopentanoic (18\%) and other substrates used in the study, suggesting a strong preference for shorter chain length substrates. The catalytic cavity of the B. licheniformis YdaP contains some bulky residues, such as histidine and tyrosine. The presence of bulky residues within the catalytic cavity may limit the entry of larger substrates into the substrate channel. A strong preference for pyruvate and other smaller $\alpha$-keto acids substrates suggests that these may be the in vivo substrate, and the principal role of this enzyme could be the production of acetate.

The YdaP enzyme was purified to near homogeneity by ammonium sulfate precipitation, hydrophobic interaction and ion exchange chromatography. YdaP activity was initially detected by a zymogram, where a band of approximately $250 \mathrm{kDa}$ formed a precipitate in the presence of pyruvate and DCPIP as a cofactor (Fig. 4). This suggested that the active form of the $\mathrm{YdaP}$ enzyme functions as a homotetramer, a feature common for the TPP family proteins. The production of acetate was confirmed by HPLC. HPLC analysis was used to validate the conversion of pyruvate by $B$. licheniformis $\mathrm{YdaP}$ to acetate. However, acetate was produced at a constant concentration of approximately $1 \mathrm{mM}$, irrespective of the substrate concentration. Similar results were obtained in previous studies of acetate production, like the $0.96 \mathrm{mM}$ reported for C. glutamicum POX (Schreiner \& Eikmanns, 2005). It is likely that these results reflect a reaction limitation imposed by the concentration of the DCPIP electron acceptor $(300 \mu \mathrm{M})$ added to the reaction. The stoichiometric reaction of DCPIP in the enzyme assay leads to speculate that the DCPIP could be limiting the completion of conversion of the substrate to acetate. Therefore, the obtained result suggests that the increasing of the DCPIP concentration might increase the acetate product. The presented study describes and validates a HPLC method for determination of acetate as a method of choice. It is likely that HPLC has the potential to rapidly identify and quantify acetate, and could be a significant contributor in development and screening of acetate products within a family of pyruvate oxidases.

The 3 Dimension structural model of YdaP of B. licheniformis was constructed based on the closest similarity to the experimentally determined structure of $L p$ POX (Wille et al., 2006). Despite the overall identities between the primary structures of the $\mathrm{YdaP}$ enzyme from $B$. licheniformis and the $L$. plantarum pyruvate oxidase, the alignment studies revealed some common features in the $L$. plantarum pyruvate oxidase. The overall topology of the $B$. licheniformis $\mathrm{YdaP}$ was similar to the known pyruvate oxidase crystal structures (Neumann et al., 2008). The structural model generated was assessed and revealed to be in a good agreement with template structure suggesting the accuracy spectrum of the $B$. licheniformis YdaP model.

The structure of the ThDP motif was identical to that found in the other pyruvate oxidases and the residues (Asp313 and Ala314) (Muller \& Schulz, 1993; Muller et al., 1994), suggested to be involved in metal ion cofactor binding $\left(\mathrm{MgCl}_{2}\right)$ and also showed positional conservation (Neumann et al., 2008).

YdaP showed a preference for short chain length substrates, suggesting that the dimensions of the active site might be relatively small. A comparison of the YdaP active site binding pocket with that of other pyruvate oxidases (Muller et al., 1994) showed that bulky hydrophobic amino acid residues Tyr469, His476 and Tyr479 formed part of the active site cavity in YdaP. In L. plantarum POX, these correspond to amino acid residues Trp479, Ile480 and Glu483. These residues are presumably critical for the catalytic activity of pyruvate oxidases, and have been proposed to be involved in substrate binding. This observation suggested that these residues would negatively influence the accessibility of large substrates (e.g., aromatic) into the catalytic centre, thereby restricting the activity of $\mathrm{YdaP}$ for short chain substrates. This information may assist in studies aimed at engineering the catalytic active site of the enzyme to improve accessibility of larger substrates into the active site.

\section{Acknowledgement}

The authors gratefully acknowledge TMO Renewable and the National Research Foundation for the financial support of this project.

\section{REFERENCES}

Altschul SF, Madden TL, Schaffer AA, Zang JZ, Miller W, Lipman DJ (1997) Gapped BLAST and PSI-BLAST: a new generation of protein database search programs. Nucleic Acids Res 25: 3389-3402. doi: $10.1093 /$ nar/25.17.3389

Bertagnolli BL, Hager LP (1991) Activation of Escherichia coli pyruvate oxidase enhances the oxidation of hydroxyethylthiamin pyrophosphate. J Biol Chem 266: 10168-10173 
Blake R, O’Brien TA, Gennis RB, Hager LP (1982) Role of the divalent metal cation in the pyruvate oxidase reaction. J Biol Chem 257: 9605-9611

Blake R, Hager LP (1978) Activation of pyruvate oxidase by monomeric and micellar amphiphiles. J Biol Chem 253: 1963-1971

Chang YY, Cronan JE, Jr (1986) Molecular cloning, DNA sequencing, and enzymatic analyses of two Escherichia coli pyruvate oxidase mutants defective in activation by lipids. J Bacteriol 167: 312-318

Chang YY, Cronan JE, Jr (1988) Common ancestor of Escherichia coli pyruvate oxidase and the acetohydroxy acid synthases of the branched-chain amino acid biosynthetic pathway. J Bacteriol 170: 3937-3945

Chang YY, Cronan JE, Jr (1995) Detection by site-specific disulfide cross-linking of a conformational change in binding of Escherschia coli pyruvate oxidase to lipid bilayers. J Biol Chem 270: 7896-7901

Claus SC, Berkeley RCW (1986) Genus Bacillus cohn 1872. In Sneath PHA et al., eds. pp 1105-1139. Baltimore, MD: Williams and Wilkins Co

Cunningham CC, Hager LP (1971) Crystalline pyruvate oxidase from Escherichia coli phospholipids as an allosteric effector for the enzyme. J Biol Chem 264: 1583-1589

Duggleby RG (2006) Domain relationships in thiamine diphosphatedependent enzymes. Acc Chem Res 39: 550-557. doi: 10.1021/ ar0680222

Diallo MD, Martens M, Vloemans N, Cousin A, Vandekerckhov TTM, Neyra M, de Lajudie P, Willems A, Gillis M, Vyverman W, Van der Gucht K (2004) Phylogenetic analysis of partial bacterial 16S rDNA sequence of tropical grass pasture soil under Acacia tortilis subsp raddiana in Senegal. Syst App Microbiol 27: 238-252. doi: $10.1078 / 072320204322881862$

Erickson RJ (1976) Industrial application of the Bacilli: A review and prospectus. In Schlensiger D ed, pp 406-419. Microbiology. Washington, DC: Amer Soc Microbiol

Eveleigh DE (1981) The microbial production of industrial chemicals. Scientific American 245: 155-178

Goffin P, Muscariello L, Lorquet F, Stukkens A, Prozzi D, Sacco M, Kleerebezem M, Hols P (2006) Involvement of pyruvate oxidase activity and acetate production in the survival of Lactobacillus plantarum during the stationary phase of aerobic growth. Appl Environ Microbiol 72: 7933-7940. doi: 10.1128/AEM.00659-06

Grabski A, Mehler M, Drott D (2005) The overnight expression autoinduction system: High-density cell growth and protein expression while you sleep. Nature Meths 2: 233-235. doi: 10.1038/ nmeth0305-233

Hall TA (1999) BioEdit: a user-friendly biological sequence alignment editor and analysis program for windows 95/98/NT. Nucleic Acids Symp Ser 95-98

Hamilton SE (1986) Identification of the high-affinity lipid binding site in Escherichia coli pyruvate oxidase. Biochemistry 25: 8178-8183. PMID: 3545288

Hawkins CF, Borger A, Perham RN (1989) A common structural motif in thiamin pyrophosphate-binding enzymes. FEMS Lett 255: 77-82.

Juan ECM, Hoque MM, Hossain MT, Yamamoto T, Imamura S, Suzuki K, Sekiguchi T, Takénaka A (2007) The structures of pyruvate oxidase from Aerococcus viridans with cofactors and with a reaction intermediate reveal the flexibility of the active-site tunnel for catalysis. Acta Crystallogr Sect F Struct Biol Cryst Commun 63: 900-907. doi: $10.1107 / \mathrm{s} 1744309107041012$

Lorquet F, Goffin P, Muscariello L, Baudry JB, Ladero V, Sacco M, Kleerebezem M, Hols P (2004) Characterization and functional analysis of the poxB gene, which encodes pyruvate oxidase in Lactobacillus plantarum. J Bacteriol 186: 3749-3759. doi: 10.1128/ JB.186.12.3749-3759-2004

Lovell SC, Davis JW, Arendall WB, 3rd de Bakker PI, Word JM, Richardson MG, Richardson JS (2001) Structure validation by Calpha geometry phi, psi and C beta deviation. Proteins 50: 43-450. PMID: 12557186

Mather M, Schopfer LM, Massey V, Gennis RB (1982) Studies of the flavin adenine dinucleotide binding region in Escherichia coli pyruvate oxidase. J Biol Chem 257: 12887-12892

Miller DN, Bryant JE, Madsen EL, Ghiorse WC (1999) Evaluation and optimization of DNA extraction and purification procedures for soil sediment samples. Appl Environ Microbiol 65: 4715-4724. PMID: 10543776. PMCID: PMC 91634

Muller YA, Schulz GE (1993) Structure of the thiamine- and flavindependent enzyme pyruvate oxidase. Science 259: 965-967

Muller YA, Schumaker G, Rudolph R, Schulz GE. (1994) The refined structure of stabilized mutant and of wild-type pyruvate oxidase from Lactobacillus plantarum. J Mol Biol 237: 315-335
Neale AD, Scopes RK, Wettenhall RE, Hoogenraad NJ (1987) Pyruvate decarboxylase of Zymomonas mobilis: isolation, properties and genetic expression in Escherichia coli. J Bacteriol 169: 1024-1028. PMCID: PMC211896

Neumann P, Weidner A, Pech A, Stubbs MT, Tittmann K (2008) Structural basis for membrane binding and catalytic activation of the peripheral membrane enzyme pyruvate oxidase from Escherichia coli. Proc Nat Acad Sci 105: 17390-17395. doi: 10.1073/pnas.080527105

O'Brien TA, Blake R, Gennis RB (1977) Regulation by lipids of cofactor binding to a peripheral membrane enzyme: Binding of thiamine pyrophosphate to pyruvate oxidase. Biochemistry 16: 3105-3109

Okuyama T, Takata M, Takahashi K (1989) High-performance liquid chromatographic analysis of naturally occurring glycosides and saponins. J Chromatogr 466: 390-398. doi: 10.1016/s0021-9673(01)84636-7

Patton TG, Rice KC, Foster MK, Bayles KW (2005) The Staphylococcus aureus cidC gene encodes a pyruvate oxidase that affects acetate metabolism and cell death in stationary phase. Mol Microbiol 56: 1664 1674. doi: 10.1111/j.1365.2005.04653.x

Priest FG, Goodfellow M, Shute LA, Berkeley RCW (1987) Bacillus amyloliquefaciens sp. Nov Rev Int J Syst Bacteriol 37: 69-71. doi: 10.1099/00207713-37-1-69

Priest FG, Goodfellow M, Todd C (1988) A numerical classification of the genus Bacillus. J Gen Microbiol 134: 1847-1882. doi: 1099/00221287-134-7-1847

Radnedge L, Agron PG, Hill KH, Jackson PJ, Ticknor LO, Keim P, Andersen GL (2003) Genome differences that distinguish Bacillus anthracis from Bacillus cereus and Bacillus thuringiensis. Appl Environ Microbiol 69: 2755-2764. doi: 10.1128/AEM.69.5.2755-2764.2003

Rey MW, Ramaiya P, Nelson BA, Brody-Karpin SD, Zaretsky EJ, Tang M, Lopez de Leon A, Xiang H, Gusti V, Clausen IG, Olsen PB, Rasmussen MD, Andersen JT, Jørgensen PL, Larsen TS, Sorokin A, Bolotin A, Lapidus A, Galleron N, Ehrlich SD, Berka RM (2004) Complete genome sequence of the industrial bacterium Bacillus licheniformis and comparison with closely related Bacillus species. Genome Biol 5: R77. doi: 10.1186/gb-2004-5-10-r77

Šali A (1995) Modelling mutations and homologous proteins. Curr Opin Biotech 6: 437-451. doi: 10.1016/0958-1669(95)80074-3

San KY, Bennet GN, Aristidou AA, Chou CH (1994) Strategies in high-level expression of recombinant protein in Escherichia coli. Ann N Y Acad Sci 721: 257-267. doi: 10.1111/j.1749-6632.1994. tb47399.x

Schreiner ME, Eikmanns BJ (2005) Pyruvate: Quinone oxidoreductase from Corynebacterium glutamicum: purification and biochemical characterization. J Bacteriol 187: 862-871. doi: 10.1128/JB.187.3.862-871

Sedewitz B, Schleifer KH, Gotz F (1984) Purification and biochemical characterization of pyruvate oxidase from Lactobacillus plantarum. J Bacteriol 160: 273-278. PMCID: PMC214712.

Shi J, Blundell TL, Mizuguchi K (2001) Sequence structure homology recognition using environment-specific substitution tables and structure-dependent gap penalties. J Mol Biol 310: 243-257. doi: 10.1006/ jmbi.2001.4762

Steele, H L (2008) Advance in recovery of novel biocatalysts from metagenomes. Mol Microbiol Biotechnol 16: 25-37. doi: $10.1159 / 000142892$

Tomar A, Eiteman MA, Atman, E (2003) The effect of acetate pathway mutations on the production of pyruvate in Escherichia coli. Appl Microbiol Biotechnol 62: 76-82. doi: 10.1007/s00253-003-1234-6

Veith B, Herzberg C, Steckel S, et al., (2004) The complete genome sequence of Bacillus licheniformis DSM13, an organism with great industrial potential. I Mol Microbiol Biotechnol 7: 204-211. doi: 10.1159/000079829

Wang A. Y, Chang YY, Cronan, JE (1991) Role of the tetrameric structure of Escherichia coli pyruvate oxidase in enzyme activation and lipid binding. J Biol Chem 266: 10959-10966

Wille G, Meyer D, Steinmetz A, Hinze E., Golbik R, Tittmann K (2006) The catalytic cycle of a thiamin diphosphate enzyme examined by cryocrystallography. Nat Chem Biol 2: 324-328. doi: $10.1038 /$ nchembio.788

Yilmaztekin M, Erten H, Cabaroglu T (2008) Production of isoamyl acetate from sugar beet molasses by Williopsis saturnus var. saturnus. J Inst Brewing 114: 34-38. doi: 10.1016/j.foodchem.2008.05.079

Yoneda N, Kusano S, Yasui M, Pujado P, Wilcher S (2001) Recent advances in processes and catalysts for the production of acetic acid. Appl Catalysis 221: 253-265. doi: 10.1016/s0926-860x(01)00800-6

Zhang TF, Hager LP (1987) A single-step large-scale purification of pyruvate oxidase. Arch Biochem Biophys 257: 485-487. PMID: 3310893 